\title{
Professor emeritus I SOCIALPOLITIK GUY BÄCKMAN HAR GÅTT BORT
}

\author{
Mikael Nygård: professor i socialpolitik, Abo Akademi
}

mikael.nygard@abo.fi

Janus vol. 29 (2) 2021, 196-197

Professor emeritus Guy Bäckman har gått ur tiden. Med detta har en idog forskare, en omtyckt lärare och en uppskattad kollega slutgiltigt lagt sin penna till ro. Bäckman föddes den sjätte april 1940 i Nagu och blev student från Svenska Lyceet i Helsingfors år 1960. Efter studentexamen sökte han in till Helsingfors Universitet där han avlade politices kandidatexamen 1965 , politices magisterexamen 1966 samt politices doktorsexamen 1969. Bäckman inledde sin professionella bana vid Socialministeriet där han fungerade som biträdande aktuarie och aktuarie under åren 1964-1967. Efter tjänstgöringen vid ministeriet flyttade han till Statistiska centralbyrån där han fungerade som aktuarie och överaktuarie under åren 1967-1969. Bäckman återvände till den akademiska världen år 1970 då han tog emot tjänsten som överlärare i socialpolitik vid Social och Kommunalhögskolan, en befattning han innehade fram till år 1976. Under en kort period år 1970 fungerade han även som assistent och lektor vid Nordiska hälsovårdsskolan i Göteborg. Bäckman erhöll år 1971 titeln docent vid Helsingfors Universitet och skötte även under åren 1972-1974 en tjänst som biträdande professor/t.f. professor vid samma universitet. Efter denna sejour styrdes kosan år 1974 mot Åbo, där Guy kom att verka under återstoden av sin akademiska karriär. Han beviljades år 1973 en docentur i socialpolitik vid Åbo Akademi, och axlade följande år ansvaret som t.f. professor i socialpolitik vid samma universitet. År 1976 utnämndes Bäckman till professor i socialpolitik vid Åbo Akademi, en befattning som han innehade fram till sin pensionering. Efter pensioneringen fortsatte han emellertid att bedriva forskning och att publicera verk.

Till Bäckmans främsta forskningsintressen hörde hälso- och sjukvårdsrelaterade frågor, bland annat frågan om hur hälsan påverkas av individuella och miljörelaterade faktorer. Bland hans tidigare publikationer kan nämnas "Työikäiset miehet sairaalapalvelusten kuluttajina" (1969), "Psychosocial environment and health" (1984), "Yksilö, lähiympäristö ja terveys (1987, svensk översattning Individ, närmiljö och hälsa, 1991) samt "The enigma of health: the case of Japan" (1999). Under sina sista år var han speciellt intresserad av digitaliseringens och automationens betydelse för framtidens socialpolitik och i synnerhet äldreomsorgen. Till hans sista verk hör speciellt "Social Policy on the Cusp:Values, Institutions and Change" (2020) och "The Global Economy and Welfare in a Digital Age" (2020).

Vid sidan av sin professur skötte Bäckman även flera förtroende- och he- 
dersuppdrag, både inom den akademiska världen och utanför. Under åren 1990-1993 tjänstgjorde han bland annat som dekanus för Åbo Akademis ekonomisk-statsvetenskapliga fakultet. Han fungerade som Socialpolitiska föreningens i Finland ordforrande under åren 1976-1978, som ledamot av Finlands Akademis samhällsvetenskapliga kommitté 1979-1982 samt som ledamot av Finska Vetenskaps-Societeten sedan år 1989. Han var också en internationellt förankrad forskare med flera utlandsvistelser bakom sig. Han vistades bland annat som gästföreläsa- re vid UCLA (Berkeley), USA, under perioden 1983-1984, som gästprofessor vid Sheffield University, Storbritannien under år 1992 samt i flera repriser som gästprofessor i Japan under 1990-talet. Bäckmans engagemang för barn och deras välfärd framgår av att hans aktivitet i Kiwanis Club där han även fungerade som president för dess Åbo-avdelning och som guvernör för Norden-distriktet.

Bäckman sörjs av sina anhöriga, vänner, medarbetare och tidigare studerande. 